\title{
Leaf beetle decline in Central Europe (Coleoptera: Chrysomelidae s.I.)?*
}

\author{
Angelique Wendorff', Michael Schmitt' \\ I Ernst-Moritz-Arndt-Universität Greifswald, Allgemeine \& Systematische Zoologie, Loitzer Str. 26, D-17489 \\ Greifswald, Germany \\ Corresponding author: Michael Schmitt (michael.schmitt@uni-greifswald.de)
}

Academic editor: M. Biondi | Received 19 December 2018 | Accepted 13 February 2019 | Published 17 June 2019

http://zoobank.org/13713C89-7CC9-42BB-AA23-CD2FFE5D8E40

Citation: Wendorff A, Schmitt M (2019) Leaf beetle decline in Central Europe (Coleoptera: Chrysomelidae s.l.)? In: Schmitt M, Chaboo CS, Biondi M (Eds) Research on Chrysomelidae 8. ZooKeys 856: 115-135. https://doi. org/10.3897/zookeys.856.32564

\begin{abstract}
Based on 168,674 records in the database ChryFaun changes in distribution and abundance of leaf beetles (Chrysomelidae s.1.) in Central Europe were analysed from 1900 through 2009. From the first decade (1900-1909) to the last (2000-2009) the number of records per decade increased by factor 26, from 1513 to 41,269 . The number of species increased from 395 in decade 1 to 606 in decade 10 , but only 532 were reported in decade 11. The number of species with fewer records increased from 1990 although the total number of records increased continuously. Decrease and increase is found likewise in mono-, oligo-, and polyphagous species. Twenty-two species (3.0\%) have not been reported since 1990, and 42 (5.8\%) since $2000.71 \%$ of all taxa reported between 2000 and 2009 had fewer records than in the immediately previous decade. These indications of decline correspond with numerous published studies on decline in other groups of arthropods. Analysis shows that data from private and public collections are useful for the retrospective analysis of numbers and distributions of leaf beetles (and other organisms).
\end{abstract}

\section{Keywords}

abundance, collection data, geographical distribution, insect decline

extended versions of a talk presented to the $3^{\text {rd }}$ European Symposium on the Chrysomelidae, Naples, Italy, 5 July, 2018. 


\section{Introduction}

The alarming news that the biomass of flying insects decreased by $75 \%$ in the course of the past 30 years (Hallmann et al. 2017) raised a remarkable public awareness of the general decline of biodiversity in Europe and elsewhere. Earlier studies (e.g., Thomas et al. 2004; Conrad et al. 2006; Kosior et al. 2007) had pointed in the same direction but were hardly noticed by the media and decision makers. Biesmeijer et al. (2006) had even demonstrated a parallel decline of pollinators and insect-pollinated plants in The Netherlands.

There is an ongoing controversy as to the causation of this process. Change in land use and intensified agriculture, loss or fragmentation of habitats, and the global climate change are considered as possible causes (see Conrad et al. 2006; Potts et al. 2010; Hallmann et al. 2017). The average temperature in Europe increased between 2006 and 2015 by $1.45-1.59^{\circ} \mathrm{C}$ as compared to pre-industrial times (Kurnik 2017). Habitat fragmentation prevents individuals from natural dispersal so that local extinction events occur. As a consequence, smaller population sizes and a reduced ability to disperse of, e.g., Cryptocephalus nitidulus Fabricius, 1787 (Chrysomelidae: Cryptocephalinae) were observed in Britain (Piper and Compton 2010).

Changes in land use, habitats and climate certainly not only cause a decline of insects (and other organisms) but will also further range shifts and colonisation of new habitats as animals will track their preferred conditions if ever possible. In literature, we find numerous reports of an expansion or shift of ranges in beetles, butterflies, dragonflies, and grasshoppers to the north or to higher elevations (Parmesan 1996; Parmesan et al. 1999; Konvicka et al. 2003; Hickling et al. 2006), as well as spiders (Krehenwinkel and Tautz 2013) and birds (Thomas and Lennon 1999). Also leaf beetles seem to respond to increasing temperature by changing their distributional area, as shown for Oulema melanopus (Linnaeus, 1758) in Canada (Olfert and Weiss 2006) and for Leptinotarsa decemlineata (Say, 1824) and O. melanopus in Europe (Svobodova et al. 2014).

We checked if decline and distributional change also occur in leaf beetles (Chrysomelidae s.l.) in Central Europe. To accomplish this we analysed the records in the database ChryFaun for the period from 1900 to 2009 or 2017. This database was compiled by the members of the working group "Faunistics of Central European leaf and seed beetles - ChryFaun", founded in 1987 (Schmitt et al. 2014). We expected to find a number of species that extended or shifted their range northwards, and that the number of records for some species had decreased towards the end of our study period.

\section{Materials and methods}

\section{The database}

The database ChryFaun contains records from the end of the $19^{\text {th }}$ century to present, taken from museum and private collections, provided by institutions, individual amateur collectors, and regional entomological clubs (for details see Schmitt et al. 2014). Up to now (06.12.2018), 175,632 records for 726 species and 50 subspecies of Chrysomel- 
idae sensu lato (i.e., including Megalopodidae, Orsodacnidae, and Bruchinae/Bruchidae) have been entered. We follow the nomenclature in Löbl and Smetana (2010).

Operationally, "Central Europe" is defined as the rectangle between $2^{\circ}$ and $25^{\circ}$ eastern longitude and between $45^{\circ}$ and $55^{\circ}$ northern latitude. This area comprises The Netherlands, Belgium, Luxembourg, Germany, Switzerland, Liechtenstein, Austria, The Czech Republic, Slovakia, Poland, Hungary, Slovenia, and parts of France, Italy, Croatia, Serbia, Romania, Ukraine, Belarus, Russia, and Lithuania (see Fig. 1).

\section{Data analysis}

Changes in distribution

We selected 246 species or subspecies out of the 776 taxa in ChryFaun. These are (1) species for which Schmitt and Rönn (2011) gave a northern, montane, southern, southeastern or southwestern distribution; (2) species for which we found an indication of distributional change in the literature; and (3) all additional species of the genera Gonioctena, Orsodacne, Phyllotreta, Timarcha and Zeugophora, as we suspected that they may be prone to behave ecologically similar to their congeneric species with ranges of the types listed under (1).

We divided the study period (1900 through 2017) into four quartiles, quartile 1: 1900-1929, quartile 2: 1930-1959, quartile 3: 1960-1989, and quartile 4: 19902017. We generated frequency maps of the distribution of all species studied for each quartile using the distribution mapping software DMAP (Alan Morton, Penrhyncoch, Aberystwyth, Ceredigion, UK - http://www.dmap.co.uk/, Version 7.4, 32-bit). Species with fewer than 24 records for the period from 1900 through 2017 were omitted.

We compared the four maps and recorded a change in distribution if the species extended or shifted its range from at least one quartile to the next for more than one degree latitude or/and longitude. We defined nine categories of change according to the direction of extension or shift: to the north, east, south, west, northeast, northwest, southeast, southwest, and "shrinking". Since a species could extend or shift its range in more than one direction, we sorted some species to more than one category. We categorized a species distribution as "shrinking" when its range diminished, or when the species disappeared.

Increase or decrease of the number of records

Here, we considered the time period from 1900 through 2009 because we have too few entries for the last eight years and for the period prior to 1900. In the ChryFaun database are 165,506 records for the time period under study (as of January, 2019). The figures for each of the 11 decades were ascertained, and increase or decrease from each decade to the following was coded qualitatively and quantitatively. The proportion of species with de- and increased records per decade were calculated, their deviation from the mean was tested with Pearson's Chi-squared test. We also tested the figures for mono-, oligo-, and polyphagous species separately. We performed $\chi^{2}$ - and Fisher's exact tests using 'R' v. 3.4.3 (R Core Team 2017). 


\section{Results}

\section{Changes of distribution}

We could not detect a change in 84 of the selected 246 taxa. The remaining 162 taxa fall in one or more than one of the described categories (Tab. 1).

\section{Increase and decrease of reported records}

The 175,632 records in ChryFaun from the time period end of $19^{\text {th }}$ century through 2017 are distributed unevenly over the area of Central Europe (Fig. 1). Approximately 114,500 records lie within Germany, with highest densities around Hamburg, in Thuringia, Saxony-Anhalt, in the Rhineland, and in the Alsace. Similarly high densities of records can be seen in eastern Austria around Lake Neusiedl, and also in the north and in the south of Poland. From some regions (white areas) we do not have records. Austria, Switzerland, Slovenia, and the major part of Germany are well covered.

We divided the study period into four quartiles, 1900-1929, 1930-1959, 19601989, 1990-2017, and identified the number of records for each quartile. The 173,981 records are distributed in a highly uneven manner, over time (Fig. 2) and in space (Fig. 3).

We have $7,412,20,473,57,251$, and 88,845 records from quartile 1, 2, 3, and 4, respectively. The geographical distribution of the records (Fig. 3a-d) shows a similar pattern for each quartile in their overall distribution (Fig. 1).

We tested the figures of the four quartiles separately for species reported as monophagous, oligophagous, or polyphagous, respectively by Koch (1992). There were no significant differences in the proportions of species with de- or increased numbers of records from one quartile to the following.

For more detailed analysis we listed the records per decade from 1900 through 2000. The time period was truncated at 2009 in order to compare full decades and because collectors often hand in their contributions with a delay. From decade 1(19001909) to decade 11 (2000-2009) the number of records in ChryFaun increased from 1513 to 40,269 , i.e., by factor 26.6 . This increase ( \pm 0.5 ) is, however, caused by records that pertain to only three species: Lochmaea crataegi (Forster, 1771), Sclerophaedon orbicularis (Suffrian, 1851), and Chrysolina staphylaea (Linnaeus, 1758). In 229 taxa (species and subspecies) the increase is lower than by factor 26, and 19 taxa show an absolute decrease in records. The factor of increase is higher than 26 in only 123 taxa. For 402 of the 776 taxa we did not calculate such factors as either the numbers of their records were constant over the eleven decades or records were missing for decade 1 or decade 11. The number of reported taxa increased from 399 in decade 1 to 657 in decade 10, but only 616 were reported in decade 11 (Fig. 4, orange line).

The number of species with increase or decrease from one decade to the following is not constant over time. There are significant deviations from equal distribution (increase: $\chi^{2}=195.18, \mathrm{df}=9$, p-value $<2.2 \mathrm{e}-16$, decrease: $\chi^{2}=323.05, \mathrm{df}=9$, $\mathrm{p}$-value $<2.2 \mathrm{e}-16$, Pearson's Chi-squared test, Fig. 5). 
Table I. Change of distribution of 162 out of the 246 selected species of Chrysomelidae s.l. in central Europe ( 58 species are sorted into more than one category).

\begin{tabular}{lc}
\hline \multicolumn{1}{c}{ Change of distribution towards } & Number of species \\
\hline North & 25 \\
East & 107 \\
South & 12 \\
West & 17 \\
North-East & 18 \\
North-West & 10 \\
South-East & 19 \\
South-West & 5 \\
Shrinking & 25 \\
\hline
\end{tabular}

The complete list of species and their assignments are given in Appendix 1.

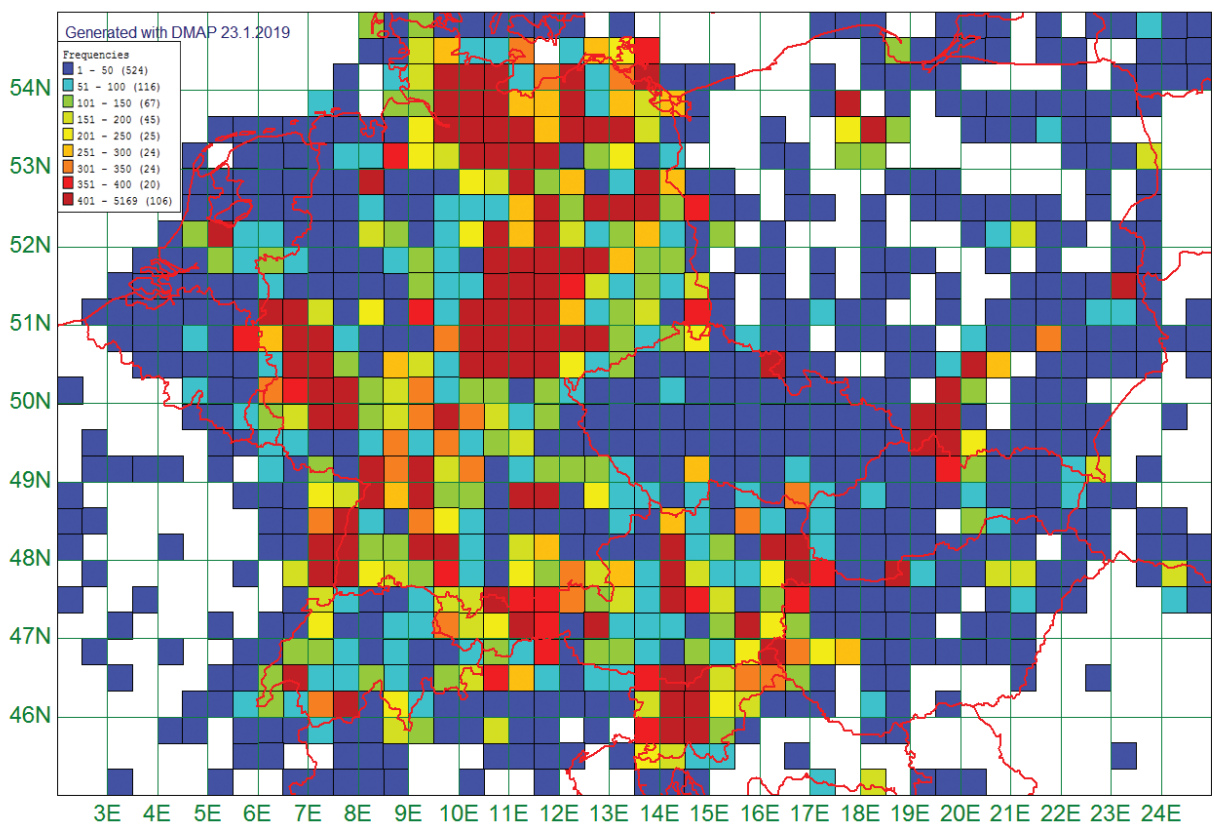

Figure I. Distribution of the 175,632 records from 951 grid fields of $20 \times 30$ geographical minutes in Central Europe.

From decade 1 through decade 9 the number of those taxa with an increase in records (orange columns in Fig. 5) increases. At the same time, the number of taxa with a decrease of records (blue columns in Fig. 5) remains relatively constant, with the exception of the changes from decade 3 to 4 and from 4 to 5 . Beginning with decade 9 (1990), our data show obvious changes. There are fewer taxa with an increase of records whereas there are considerably more taxa with a decrease of records. From decade 10 to 11 more taxa showed a decrease than an increase of records (Fig. 5).

In decade 10 (1990-1999) 22 species were no longer reported that were present in the previous decades. In decade 11 this figure increased to 42 species (see Appendix 2). 


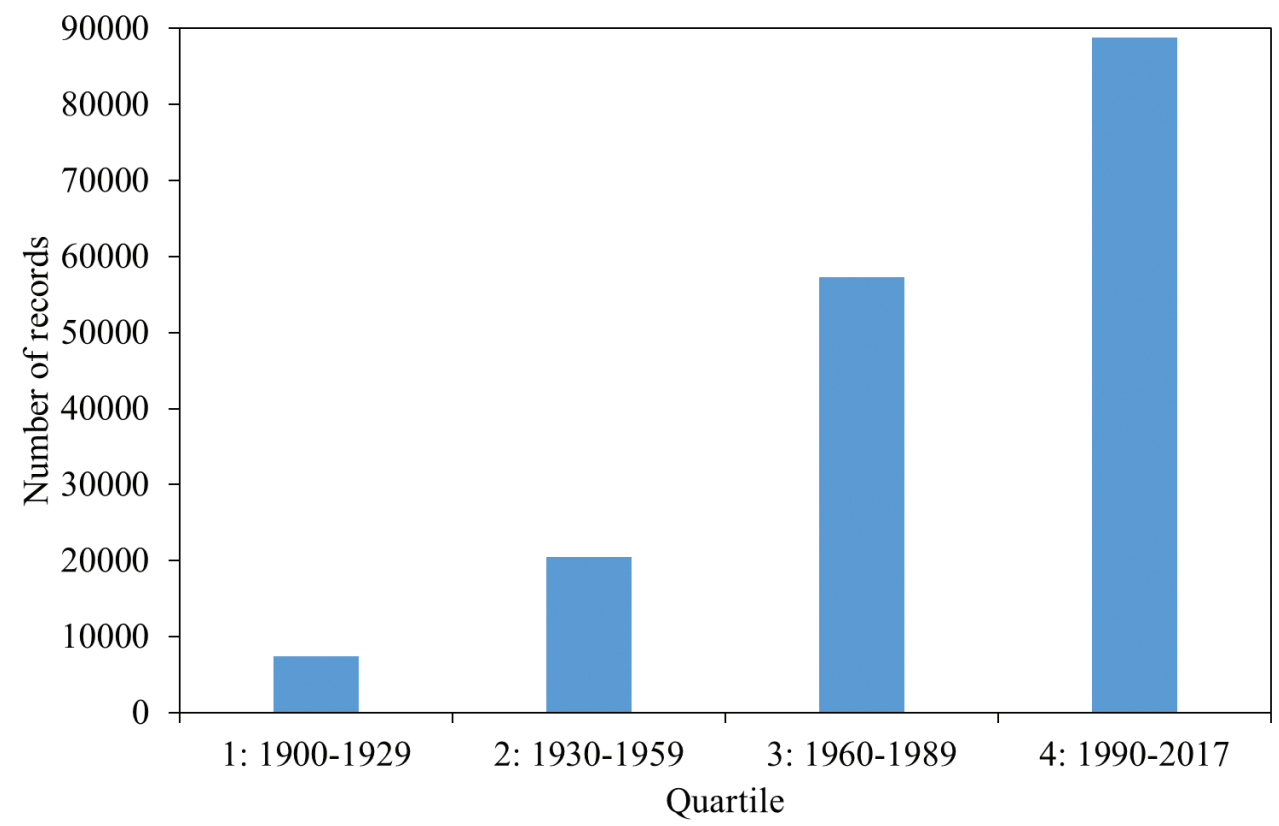

Figure 2. Numbers of records of Chrysomelidae s.l. in ChryFaun per quartile.
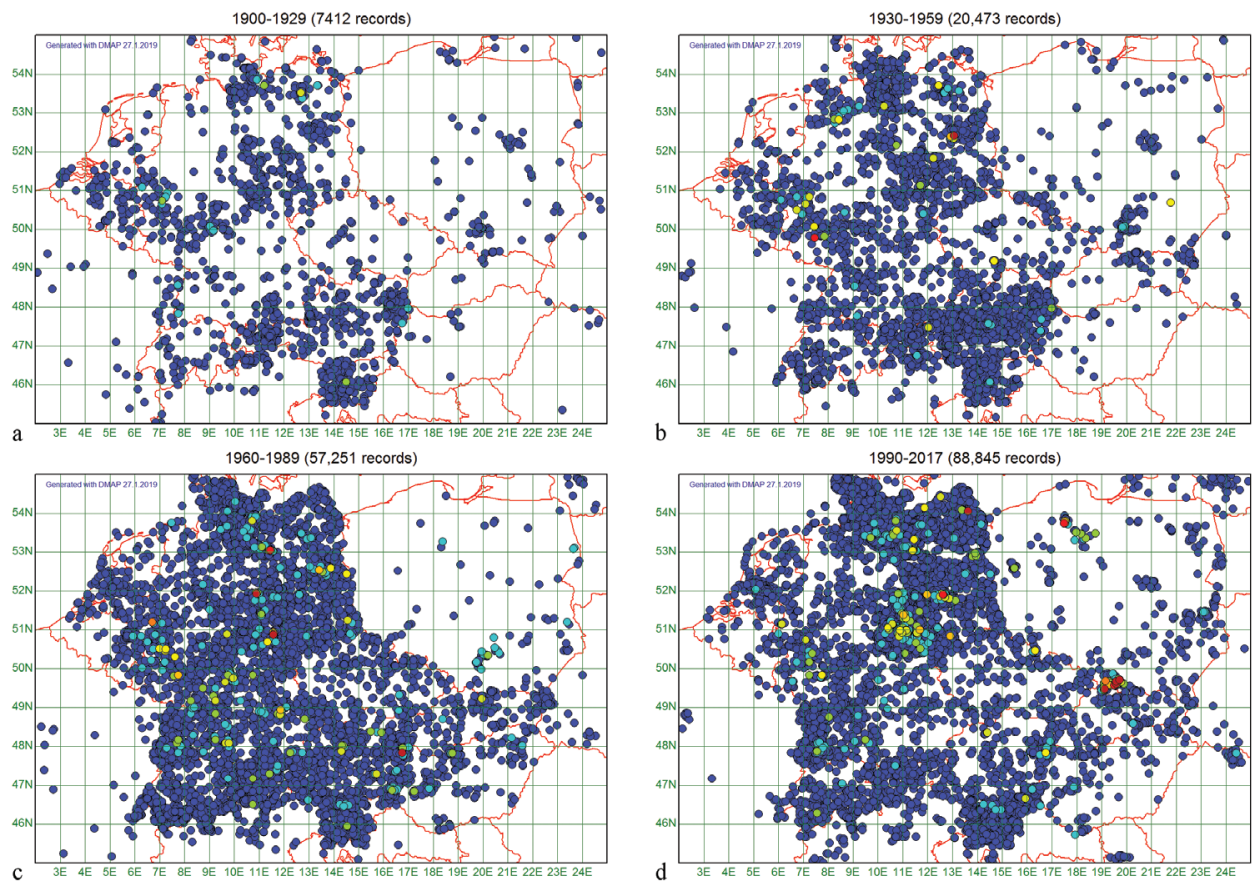

Figure 3. Geographical distribution of the records in ChryFaun for the four temporal quartiles shown as circles of $12.5 \times 20$ geographical minutes diameter. a 1900-1929 b 1930-1959 c 1960-1989 d 1990-2017. 


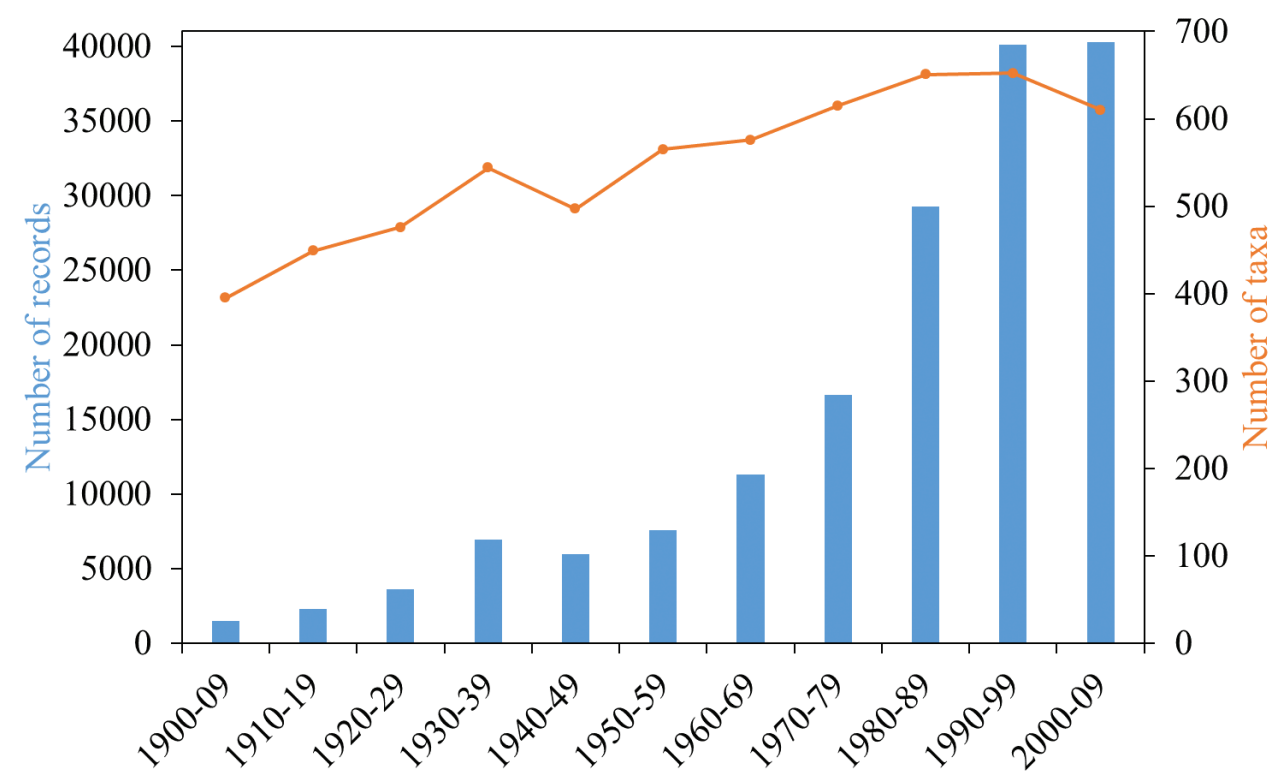

Decades

Figure 4. Number of records (blue columns) and number of reported taxa (species and subspecies -orange line) per decade between 1900 and 2009.

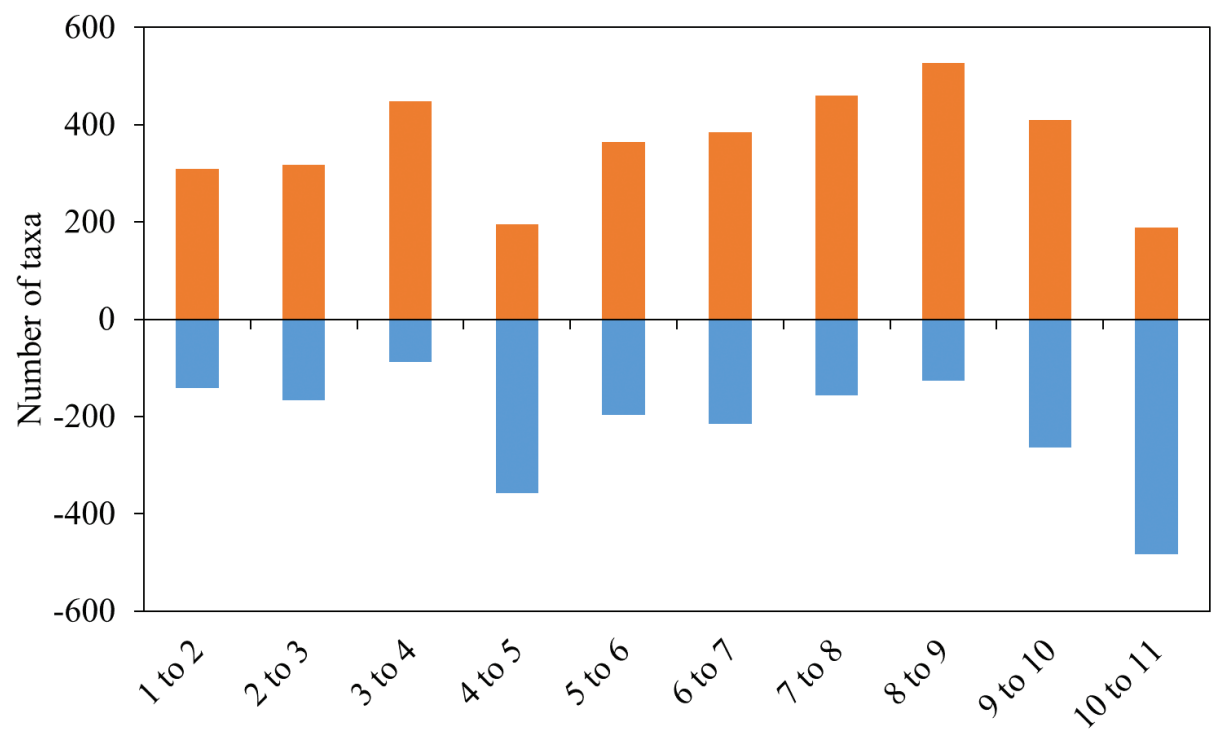

Change to decade

Figure 5. Number of taxa with an increase (orange) or a decrease (blue) of records from one decade to the following. The figures for increase and for decrease differ significantly from equal distribution (Pearson's Chi-squared test: $\chi^{2}=195.18, \mathrm{df}=9$, $\mathrm{p}$-value $<2.2 \mathrm{e}-16$ for the increase values, $\chi^{2}=323.05, \mathrm{df}=9, \mathrm{p}$-value $<2.2 \mathrm{e}-16$ for the decrease values). 
Species that "disappeared" from Germany are e.g., Ochrosis ventralis (Illiger, 1807) and Psylliodes luteola (Müller, 1776). However, records from other areas, e.g., the Czech Republic exist for both species (Čižek 2006). The most recent record of Entomoscelis adonidis (Pallas, 1771) in whole Central Europe, e.g., is of 1982. From decade 10 to decade 11 only 192 taxa were reported with increased record numbers. Of these taxa, only eight species with more than 250 records each contributed 3,509 records to the total number. In decade 11, we had records of 687 taxa in total. Of these, 486 (71\%) were reported with fewer records than in decade 10 .

\section{Discussion}

Our database shows that the number of reported species decreased in the last decade although the total number of records increased (Fig. 4). This total increase of records is caused by only few highly abundant species. Our assessment suggests a decline in seed and leaf beetles in Central Europe since 1990. However, there are serious caveats: the continuous increase of records from 1900 to 2009 or 1900 to 2017, respectively (Figs 4, 2 ), reflects the activity of the collectors whose specimens are stored in the public collections we could exploit, and the motivation of those amateur collectors who reported their data to us or who published their findings. The activity of the amateur and professional collectors who contributed data varied over time and space. There are regions in Central Europe where entomological clubs are active whereas in others there are no such associations. Additionally, amateurs tend to collect in areas highly attractive to tourists, and where they expect a high diversity and abundance of the species in which they are interested. A major consequence is the inhomogeneous coverage of records over our study area (Fig. 1). Also, numerous collectors focus on certain subtaxa, sometimes even single genera, and ignore the remaining seed and leaf beetle species (see also Rheinheimer and Hassler 2018: 52). However, data on widespread and common species can also yield useful information on a possible biodiversity crisis (Conrad et al. 2006) but are probably underrepresented in our database. The collected specimens were identified to species or subspecies by taxonomists of different levels of expertise. Thus, our database likely contains some taxonomically incorrect records. During the past 20 years, a considerable number of leaf beetle taxonomists died, and only few younger taxonomists specialised on Chrysomelidae (E Geiser, Salzburg, pers. comm 2018, J Bezděk, Brno, pers. comm. 2019). As a consequence, the proportion of erroneous records probably increased because individuals of rare species were overlooked or incorrectly identified. This could in part explain the list of species with missing entries in ChryFaun since 1990 or 2000.

In the course of the last 100 years, the number of collected and reported seed and leaf beetles increased (Fig. 4). The number of reported species or subspecies increased more or less continuously from 1900 to 1999 but decreased markedly in the decade from 2000 to 2009. We conclude that there are fewer species of Chrysomelidae s.l. in Central Europe today than in 1990. Moreover, we consider the significant increase of the number of the species with decreased records during the last two decades of 
our study period as an indication of a serious threat to leaf beetle diversity. Quite a remarkable number of species has not been reported since 1990, and even more since 2000 (see Appendix 2). Even if we take into account that many of these "disappeared" species were or are rare and/or occur in areas from where we have only a limited number of records at all, we argue that the missing records are an alarming indication of a disappearance or even extinction in nature. Winkelman and Beenen (2010) found that a similar number of leaf beetle species had disappeared from the fauna of The Netherlands since 2000. Even some introduced stored-product pest species (marked with an * in Appendix 2) were no longer reported after 2000. We decided not to omit them from our list as this decrease of records might be indicative of factors that also influence the data on non-pest species.

Several authors, e.g., Thomas and Lennon (1999), Hickling et al. (2006), and Mason et al. (2015) discuss a general latitudinal expansion or shift of ranges of numerous invertebrate and vertebrate species as a consequence of global warming, as was found for the spider Argiope bruennichi (Scopoli, 1772) (Krehenwinkel and Tautz 2013). As to leaf beetles, only a surprisingly low number of species, 25 of the 246 analysed ones, meet our expectations. Our finding that 107 species now have a more eastern distribution as compared to the time period prior to 1980 , and 18 more to north-east and 19 to south-east, must be seen with great reservations since the data coverage of the eastern part of Central Europe is low, so this effect is most likely due to a strong general increase in number of records for the east. Nevertheless, even here there may be a real natural process underlying our data.

Generally, oscillations of abundances within certain limits are natural and might vary from year to year. Temperature, precipitation, plant growth, food availability, but also diseases, parasites, and predators influence the number of individuals in a given area (Rheinheimer and Hassler 2018: 52). Above all, climate change, loss or fragmentation of habitats or their degradation are discussed in literature as possible causes of species declines and/or changes of range (Thomas et al. 2004; Köhler 2010; Kosior et al. 2007; Piper and Compton 2010; Hallmann et al. 2017). According to the European Environment Agency (Kurnik 2017), the average temperature in Europe increased between 2006 and 2015 by 1.45 to $1.59^{\circ} \mathrm{C}$ as compared to the pre-industrial era. As the development and growth of ectothermic organisms like leaf beetles is strongly influenced by the ambient temperature, an increase in the number of records could reflect global warming. However, the observation that only 25 species extended their range towards north and 18 to north-east might suggest that global warming is probably not a major, or at least not a crucial, driver of range extensions of leaf beetles in Central Europe. The critical finding is that the number of species in our database decreased although the total number of records increased.

Loss and fragmentation of habitats are known to be responsible for the decline or even complete disappearance of species. Increasing mobility and economic activity, urbanisation, and expansion and change of agriculture are the drivers of changing landscapes (Opdam and Wascher 2004). Between 2000 and 2006 an area of $6256 \mathrm{~km}^{2}$ was turned from green land into settlements and traffic zones in Germany (UBA1 2018). 
At the same time the German Environment Agency (Umweltbundesamt, UBA) reports a loss of $5278 \mathrm{~km}^{2}$ of agricultural areas (fields and grassland, $1212 \mathrm{~km}^{2}$ of forests and semi-natural areas, and $434 \mathrm{~km}^{2}$ of wetlands (UBA1 2018). Additionally, the agriculture was intensified on the remaining areas (Gömann and Weingarten in press, Opdam and Wascher 2004). Hallmann et al. (2017) explained the decline of the biomass of flying insects in nature reserves by $75 \%$ over the past 27 years by these changes in agriculture. According to Kosior et al. (2007), the intensification of agriculture is responsible for the threat of $80 \%$ of the bumblebees and cuckoo bees in Western and Central Europe. The intensified forestry and agriculture is also a likely cause of the decline of butterflies (Warren et al. 2001) and moths (Conrad et al. 2006) in Great Britain.

Potts et al. (2010) state that the increased use of agrochemicals results in degradation of habitat quality. According to Biesmeijer et al. 2006, the application of agrochemicals caused a parallel decline of pollinating insects and insect-pollinated plants in The Netherlands and in Great Britain. We could not find data on the amount of pesticides applied in Europe. The German Environment Agency published only the national sales figures of the different types of pesticide products. These figures increased only minimally from 1995 to 2016 in pesticides for field crops (UBA2 2018).

In discussions on the possible causes of decline of species and biotope types, the authors of Red Lists agree that loss and fragmentation of habitats and changes in agriculture are the main driving factors (e.g., Korneck et al. 1998, Fritzlar 2011). Detailed analyses such as Heinig and Schoeller (2017) list manmade causes as the major factors of threat to leaf beetle diversity, e.g., increasing rarity of suitable habitats, lowering the groundwater table, and eutrophication of water bodies. Our observations point to the same direction: fewer than expected species extended their range towards the north, mono-, oligo- and polyphagous species are affected to similar degrees, and a remarkable increase of species with fewer records began with decade 8, i.e., from 1980. The above-mentioned suspected causes of insect decline have been known for a long time, as emphatically stated by Klausnitzer and Segerer (2018).

The usable habitats are fragmented like islands on which populations are trapped (Opdam and Wascher 2004). Species can react differently to fragmentation, with specialists suffering particularly (Kotze and O'Hara 2003; Biesmeijer et al. 2006; Nilsson et al. 2008). In contrast, our data do not show significant differences in de- and increase of record numbers from one quartile to the following in the species of the three trophic types. This could mean that specialists and generalists are affected in the same way and to similar degree by the factors causing insect decline.

Insects with low dispersal ability are less prone to escape from unfavourable habitat fragments in a landscape heavily modified by human activities (Warren et al. 2001; CD Thomas et al. 2004). The leaf beetle Cryptocephalus nitidulus Fabricius, 1787 is such a case (Piper and Compton 2010).

Loss and change of habitats are major factors influencing distribution and abundance of organisms (Hughes 2000) and have certainly also an impact in Chrysomelidae s.l. Our results are in concordance with numerous studies on insect decline over the past 30 years (e.g., Biesmeijer et al. 2006; Conrad et al. 2006; Hallmann et al. 
2017; Kosior et al. 2007; Kotze and O’Hara 2003; Nilsson et al. 2008; Warren et al. 2001). However, such a parallelism is surprising because distribution and abundance of leaf beetles depend crucially on the availability of their food plants. Regrettably, data on changes of general plant distributions in Central Europe are not available.

The alarming news about the decline of insects of many different orders underpins the need for a continuous monitoring of their numbers and distribution. However, monitoring will only yield data from now on. For an analysis of past developments we do not have data meeting the standards of the monitoring (screening defined areas with identical sampling methods at regular intervals). Nevertheless, the fact that our results gained from the database ChryFaun (complete loss of ca. $6 \%$ of all species, decrease of records for $71 \%$ of all species since 2000) correspond to many other studies shows that data from private and museum collections can contribute to the analysis of insect decline. Such data are stored in numerous museum collections and even more in collections of amateurs, whose taxonomic expertise often excels that of museum curators (see Köhler 1997). It would be desirable to make collection data available for analyses of processes and possible causes of insect decline. Nevertheless, even taking all mentioned drawbacks into account, we are confident that the trends our results suggest are not mere artefacts but can be considered reliable proxies for real processes in nature.

\section{Acknowledgements}

We thank the members of the ChryFaun working group, the entomological associations of Hamburg, Thuringia, and Saxony-Anhalt, the natural history museums of Bern (Switzerland), Bonn, Braunschweig, Greifswald, and Waren/Müritz, the databases GBIF and ZOBODAT and the private collectors Manfred Döberl ( ${ }^{*} \dagger$, Abensberg), Horst Kippenberg (Herzogenaurach), and Klaus Renner (Bielefeld) for making their data available. We are grateful to Pierick Mouginot (Greifswald) for statistical advice, and to Gabriele Uhl (Greifswald), Jan Bezděk (Brno), and Matthias Schöller (Berlin) for valuable feedback on our manuscript, and to the Zoologisches Forschungsmuseum Alexander Koenig (Bonn), the department of General and Systematic Zoology at the University of Greifswald (Prof Dr Gabriele Uhl), and the Bayer AG - Crop Science Division, Bee Care (Monheim am Rhein) for financial support.

\section{References}

Biesmeijer JC, Roberts SPM, Reemer M, Ohlemüller R, Edwards M, Peeters T, Schaffers AP, Potts SG, Kleukers R, Thomas CD, Settele J, Kunin WE (2006) Parallel declines in pollinators and insect-pollinated plants in Britain and the Netherlands. Science 313:351-354. https://doi.org/10.1126/science.1127863

** Manfred Döberl passed away on 12 May 2016. 
Čižek P (2006) Dřepčíci (Coleoptera: Chrysomelidae: Alticinae) Česka a Slovenska. Mětské muszeum, Nové Město nad Metují, 76 pp.

Conrad KF, Warren MS, Fox R, Parsons MS, Woiwod IP (2006) Rapid declines of common, widespread British moths provide evidence of an insect biodiversity crisis. Biological Conservation 132: 279-291. https://doi.org/10.1016/j.biocon.2006.04.020

Fritzlar F (2011) Rote Liste der Blattkäfer (Insecta: Coleoptera: Chrysomelidae) Thüringens. Naturschutz Report Thüringen 26: 250-260.

Gömann H, Weingarten P (in press) Landnutzungswandel. In: Handwörterbuch der Stadt- und Raumentwicklung. Akademie für Raumforschung und Landesplanung, Hannover, 14. Available from: https://literatur.thuenen.de/digbib_extern/dn059218.pdf [March 31, 2018] Hallmann CA, Sorg M, Jongejans E, Siepel H, Hofland N, Schwan H, Stenmans W, Müller A, Sumser H, Hörren T, Goulson D, de Kroon H (2017) More than 75 percent decline over 27 years in total flying insect biomass in protected areas. PloS One 12: e0185809. https:// doi.org/10.1371/journal.pone.0185809

Heinig U, Schöller M (2017) Rote Liste und Gesamtartenliste der Blattkäfer (Chrysomelidae und Megalopodidae) von Berlin. Der Landesbeauftragte für Naturschutz und Landschaftspflege/Senatsverwaltung für Umwelt, Verkehr und Umweltschutz, Berlin, 38 pp.

Hickling R, Roy DB, Hill JK, Fox R, Thomas CD (2006) The distributions of a wide range of taxonomic groups are expanding polewards. Global Change Biology 12: 450-455. https:// doi.org/10.1111/j.1365-2486.2006.01116.x

Hughes L (2000) Biological consequences of global warming: is the signal already. Trends in Ecology \& Evolution 15: 56-61. https://doi.org/10.1016/S0169-5347(99)01764-4

Klausnitzer B, Segerer AH (2018) Stellungnahme zum Insektensterben. DGaaE-Nachrichten 32(2): 72-80.

Koch K (1992) Die Käfer Mitteleuropas. Band 3. Ökologie. Goecke \& Evers Verlag, Krefeld, $389 \mathrm{pp}$.

Köhler F (1997) Amateurwissenschaft, Entwicklung, Beschreibung und wissenschaftssoziologische Analyse am Beispiel der Koleopterologie. Decheniana Beiheft 36: 351-420.

Köhler F (2010) Die klimabedingte Veränderung der Totholzkäferfauna (Coleoptera) des nördlichen Rheinlandes. Wald und Holz NRW, Münster, 198 pp.

Konvicka M, Maradova M, Benes J, Fric Z, Kepka P (2003) Uphill shifts in distribution of butterflies in the Czech Republic: effects of changing climate detected on a regional scale. Global Ecology and Biogeography 12: 403-410. https://doi.org/10.1046/j.1466-822X.2003.00053.x

Korneck D, Schnittler M, Klingenstein F, Ludwig G, Takla M, Bohn U, May R (1998) Warum verarmt unsere Flora? Auswertung der Roten Liste der Farn- und Blütenpflanzen Deutschlands. Schriftenreihe für Vegetationskunde 29: 299-444.

Kosior A, Celary W, Olejniczak P, Fijal J, Król W, Solarz W, Plonka P (2007) The decline of the bumble bees and cuckoo bees (Hymenoptera: Apidae: Bombini) of Western and Central Europe. Oryx 41: 79. https://doi.org/10.1017/S0030605307001597

Kotze DJ, O’Hara RB (2003) Species decline - but why? Explanations of carabid beetle (Coleoptera, Carabidae) declines in Europe. Oecologia 135: 138-148. https://doi.org/10.1007/ s00442-002-1174-3 
Krehenwinkel H, Tautz D (2013) Northern range expansion of European populations of the wasp spider Argiope bruennichi is associated with global warming-correlated genetic admixture and population-specific temperature adaptations. Molecular Ecology 22: 2232-2248. https://doi.org/10.1111/mec.12223

Kurnik B (2017) 3.2 Atmosphere. In: Climate change, impacts and vulnerability in Europe 2016: an indicator-based report. European Environment Agency, Copenhagen, 69-89. https://publications.europa.eu/en/publication-detail/-/publication/794dcba3-e922-11e6ad7c-01aa75ed71a1 [January 10, 2018]

Löbl I, Smetana A (2010) Catalogue of Palaearctic Coleoptera vol. 6 Chrysomeloidea. Apollo Books, Stenstrup, 924 pp.

Mason SC, Palmer G, Fox R, Gillings S, Hill JK, Thomas CD, Oliver TH (2015) Geographical range margins of many taxonomic groups continue to shift polewards. Biological Journal of the Linnean Society 115: 586-597. https://doi.org/10.1111/bij.12574

Nilsson SG, Franzén M, Jönsson E (2008) Long-term land-use changes and extinction of specialised butterflies. Insect Conservation and Diversity 1: 197-207. https://doi. org/10.1111/j.1752-4598.2008.00027.x

Olfert O, Weiss RM (2006) Impact of climate change on potential distributions and relative abundances of Oulema melanopus, Meligethes viridescens and Ceutorhynchus obstrictus in Canada. Agriculture, Ecosystems \& Environment 113: 295-301. https://doi. org/10.1016/j.agee.2005.10.017

Opdam P, Wascher D (2004) Climate change meets habitat fragmentation: linking landscape and biogeographical scale levels in research and conservation. Biological Conservation 117: 285-297. https://doi.org/10.1016/j.biocon.2003.12.008

Parmesan C (1996) Climate and species' range. Nature 382: 765-766. https://doi. org/10.1038/382765a0

Parmesan C, Ryrholm N, Stefanescu C, Hill JK, Thomas CD, Descimon H, Huntley B, Kaila L, Kullberg J, Tammaru T, Tennent WJ, Thomas JA, Warren M (1999) Poleward shifts in geographical ranges of butterfly species associated with regional warming. Nature 399: 579-583. https://doi.org/10.1038/21181

Piper RW, Compton SG (2010) Population size and dispersal ability of Cryptocephalus nitidulus (Linnaeus, 1758) (Col.: Chrysomelidae). Entomologist's Record and Journal of Variation 122: 257.

Potts SG, Biesmeijer JC, Kremen C, Neumann P, Schweiger O, Kunin WE (2010) Global pollinator declines: trends, impacts and drivers. Trends in Ecology \& Evolution 25: 345-353. https://doi.org/10.1016/j.tree.2010.01.007

R Core Team (2017) R: A language and environment for statistical computing. R Foundation for Statistical Computing, Vienna. https://www.R-project.org/

Rheinheimer J, Hassler M (2018) Die Blattkäfer Baden-Württembergs. Kleinsteuber Books, Karlsruhe, 928 pp.

Schmitt M, Rönn, T (2011) Types of geographical distribution of leaf beetles (Chrysomelidae) in Central Europe. ZooKeys 157 (Research on Chrysomelidae 3): 131-158. https://doi. org/10.3897/zookeys.157.1798 
Schmitt M, Bäse W, Beenen R, Drovenik B, Fritzlar F, Geiser E, Jäckel R, Langer M, Mauser J, Ringel H, Schöller M, Siede D (2014) Das Projekt ChryFaun - Faunistik der mitteleuropäischen Blatt- und Samenkäfer (Chrysomelidae s.l.). Entomologische Blätter und Coleoptera 110: 33-38.

Svobodová E, Trnka M, Dubrovský M, Semerádová D, Eitzinger J, Štěpánek P, Žalud Z (2014) Determination of areas with the most significant shift in persistence of pests in Europe under climate change. Pest Management Science 70: 708-715. https://doi.org/10.1002/ps.3622

Thomas CD, Lennon JJ (1999) Birds extend their ranges northwards. Nature 399: 213. https:// doi.org/10.1038/20335

Thomas CD, Cameron A, Green RE, Bakkenes M, Beaumont LJ, Collingham YC, Erasmus BF, De Siqueira MF, Grainger A, Hannah L, Hughes L, Huntley B, van Jaarsveld AS, Midgley GF, Miles L, Ortega-Huerta MA, Peterson AT, Phillips OL, Williams SE (2004) Extinction risk from climate change. Nature 427: 145-148. https://doi.org/10.1038/nature02121

Thomas JA, Telfer MG, Roy DB, Preston CD, Greenwood JD, Asher J, Fox R, Clarke RT, Lawton JH (2004) Comparative Losses of British Butterflies, Birds, and Plants and the Global Extinction Crisis. Science 303: 1879-1881. https://doi.org/10.1126/science.1095046

UBA1 (2018) UBA1 https:/www.umweltbundesamt.de/daten/flaeche-boden-land-oekosysteme/boden/landbedeckung-landnutzung\#textpart-1 [last access 23.10.2018]

UBA2 (2018) UBA2 https:/www.umweltbundesamt.de/daten/land-forstwirtschaft/pflanzenschutzmittelverwendung-in-der\#textpart-1 [last access 23.10.2018]

Warren MS, Hill JK, Thomas JA, Asher J, Fox R, Huntley B, Roy DB, Telfer MG, Jeffcoate S, Harding P, Jeffcoate G, Willis SG, Greatorex-Davies JN, Moss D, Thomas CD (2001) Rapid responses of British butterflies to opposing forces of climate and habitat change. Nature 414: 65-69. https://doi.org/10.1038/35102054

Winkelman JK, Beenen R (2010) Chrysomelidae - haantjes (excl. Bruchinae). In: Nederlandse Entomologische Vereniging (Ed.) Catalogus van de Nederlands kevers (Coleoptera). Monografieën van de Nederlandse Entomologische Vereniging 11: 149-158, 183-186. 


\section{Appendix I}

Table 2. List of species and their change in distribution $(\mathrm{N}$ - north, $\mathrm{E}$ - east, $\mathrm{S}$ - south, $\mathrm{W}$ - west, $\mathrm{NE}$ north-east, NW - north-west, SE - south-east, SW - south-west, Sh - shrinking, / - no change).

\begin{tabular}{|c|c|c|}
\hline $\begin{array}{l}\text { Types of geographical distributio } \\
\text { (Schmitt and Rönn 2011) }\end{array}$ & Name of species & $\begin{array}{c}\text { Change in } \\
\text { distribution }\end{array}$ \\
\hline \multirow[t]{6}{*}{ Not specified } & Diabrotica virgifera LeConte, 1858 & 1 \\
\hline & Gonioctena arctica Mannerheim, 1853 & Sh \\
\hline & Gonioctena nivosa (Suffrian, 1851) & 1 \\
\hline & Oulema septentrionis (Weise, 1880) & 1 \\
\hline & Phyllotreta balcanica Heikertinger, 1909 & I \\
\hline & Phyllotreta consobrina (Curtis, 1837) & l \\
\hline \multirow[t]{10}{*}{ Fewer than 10 records } & Gonioctena flavicornis (Suffrian, 1851) & 1 \\
\hline & Gonioctena kaufmanni (Miller, 1880) & 1 \\
\hline & Gonioctena variabilis (Olivier, 1790) & 1 \\
\hline & Phyllotreta acutecarinata Heikertinger, 1941 & l \\
\hline & Phyllotreta hochetlingeri Fleischer, 1917 & l \\
\hline & Phyllotreta variipennis (Boieldieu, 1859) & I \\
\hline & Phyllotreta ziegleri Lohse, 1980 & l \\
\hline & Timarcha gibba (Hagenbach, 1825) & I \\
\hline & Timarcha rugulosa Herrich-Schaeffer, 1838 & 1 \\
\hline & Zeugophora turneri Power, 1863 & 1 \\
\hline Alpine & Gonioctena holdhausi (Leeder, 1950) & 1 \\
\hline \multirow{3}{*}{ Fragmented } & Phyllotreta atra (Fabricius, 1775) & $\mathrm{N}, \mathrm{SE}$ \\
\hline & Phyllotreta cruciferae (Goeze, 1777) & E, SE \\
\hline & Phyllotreta striolata (Fabricius, 1803) & E, SE \\
\hline \multirow[t]{18}{*}{ Montane } & Aphthona ovata Foudras, 1860 & NW \\
\hline & Calomicrus gularis (Gredler, 1857) & I \\
\hline & Chaetocnema angustula (Rosenhauer, 1847) & l \\
\hline & Chrysolina aurichalcea (Mannerheim, 1825) & l \\
\hline & Cryptocephalus nitidulus Fabricius, 1787 & $\mathrm{E}$ \\
\hline & Longitarsus helvolus Kutschera, 1863 & I \\
\hline & Luperus viridipennis Germar, 1824 & 1 \\
\hline & Luperus xanthopoda (Schrank, 1781) & $\mathrm{N}, \mathrm{SE}$ \\
\hline & Oreina alpestris (Schummel, 1843) & E \\
\hline & Oreina bifrons (Fabricius, 1792) & $\mathrm{NE}$ \\
\hline & Oreina cacaliae (Schrank, 1785) & NE, SW \\
\hline & Oreina intricata (Germar, 1824) & $\mathrm{E}$ \\
\hline & Oreina speciosa (Linnaeus, 1767) & NE, Sh \\
\hline & Oreina speciosissima (Scopoli, 1763) & $\mathrm{NE}$ \\
\hline & Psylliodes glabra (Duftschmid, 1825) & $\mathrm{N}$ \\
\hline & Psylliodes toelgi Heikertinger, 1914 & l \\
\hline & Psylliodes vindobonensis Heikertinger, 1914 & 1 \\
\hline & Sclerophaedon carniolicus (Germar, 1824) & Sh \\
\hline \multirow[t]{8}{*}{ Northern } & Galerucella grisescens (Joannis, 1865) & E, $S$ \\
\hline & Longitarsus plantagomaritimus Dollman, 1912 & $\mathrm{E}, \mathrm{W}$ \\
\hline & Mantura chrysanthemi (Koch, 1803) & E, NW \\
\hline & Phaedon concinnus Stephens, 1831 & S \\
\hline & Phyllotreta armoraciae (Koch, 1803) & $\mathrm{N}, \mathrm{E}$ \\
\hline & Prasocuris hannoverana (Fabricius, 1775) & W \\
\hline & Psylliodes crambicola Lohse, 1954 & I \\
\hline & Psylliodes marcida (Illiger, 1807) & $\mathrm{E}, \mathrm{W}$ \\
\hline
\end{tabular}




\begin{tabular}{|c|c|c|}
\hline $\begin{array}{l}\text { Types of geographical distributio } \\
\text { (Schmitt and Rönn 2011) }\end{array}$ & Name of species & $\begin{array}{c}\text { Change in } \\
\text { distribution }\end{array}$ \\
\hline \multirow[t]{2}{*}{ Eastern } & Colaphellus sophiae (Schaller, 1783) & E, Sh \\
\hline & Phyllotreta scheuchi Heikertinger, 1941 & I \\
\hline \multirow[t]{48}{*}{ Southern } & Altica helianthemi (Allard, 1859) & S, Sh \\
\hline & Altica tamaricis Schrank, 1785 & 1 \\
\hline & Aphthona abdominalis (Duftschmid, 1825) & I \\
\hline & Aphthona atrovirens (Förster, 1849) & W \\
\hline & Aphthona cyparissiae (Koch, 1803) & 1 \\
\hline & Aphthona herbigrada (Curtis, 1837) & $\mathrm{W}$ \\
\hline & Aphthona pallida (Bach, 1856) & $\mathrm{N}$ \\
\hline & Aphthona pygmaea (Kutschera, 1861) & $\mathrm{E}$ \\
\hline & Aphthona venustula (Kutschera, 1861) & 1 \\
\hline & Apteropeda orbiculata (Marsham, 1802) & 1 \\
\hline & Derocrepis rufipes (Linnaeus, 1758) & 1 \\
\hline & Hermaeophaga mercurialis (Fabricius, 1792) & NE, SE \\
\hline & Lachnaia sexpunctata (Scopoli, 1763) & 1 \\
\hline & Neocrepidodera femorata (Gyllenhal, 1813) & $\mathrm{N}, \mathrm{E}$ \\
\hline & Ochrosis ventralis (Illiger, 1807) & W, Sh \\
\hline & Phratora tibialis (Suffrian, 1851) & $\mathrm{N}, \mathrm{E}$ \\
\hline & Phratora vulgatissima (Linnaeus, 1758) & E, $S$ \\
\hline & Phyllotreta nigripes (Fabricius, 1775) & E, SE \\
\hline & Plagiodera versicolora (Laicharting, 1781) & $\mathrm{E}$ \\
\hline & Sphaeroderma rubidum (Graëlls, 1858) & $\mathrm{E}, \mathrm{NE}$ \\
\hline & Calomicrus circumfusus (Marsham, 1802) & $\mathrm{E}$ \\
\hline & Calomicrus pinicola (Duftschmid, 1825) & $\mathrm{N}, \mathrm{W}$ \\
\hline & Cassida panzeri Weise, 1907 & E, Sh \\
\hline & Chaetocnema arida Foudras, 1860 & $\mathrm{E}$ \\
\hline & Chaetocnema obesa (Boieldieu, 1859) & $\mathrm{N}, \mathrm{E}$ \\
\hline & Chaetocnema semicoerulea (Koch, 1803) & E, Sh \\
\hline & Chrysolina cuprina (Duftschmid, 1825) & 1 \\
\hline & Chrysolina hemisphaerica (Germar, 1817) & $\mathrm{N}$ \\
\hline & Chrysolina herbacea (Duftschmid, 1825) & E, NE, SW \\
\hline & Chrysolina hyperici (Forster, 1771) & $\mathrm{E}$ \\
\hline & Chrysolina marginata (Linnaeus, 1858) & $\mathrm{E}$ \\
\hline & Chrysolina rufa (Duftschmid, 1825) & NE, Sh \\
\hline & Chrysomela cuprea Fabricius, 1775 & E, NE \\
\hline & Chrysomela saliceti (Weise, 1884) & E, Sh \\
\hline & Chrysomela vigintipunctata (Scopoli, 1763) & E, NE \\
\hline & Coptocephala rubicunda (Laicharting, 1781) & $\mathrm{E}$ \\
\hline & Crepidodera aurea (Geoffroy, 1785) & E \\
\hline & Crepidodera lamina (Bedel, 1901) & I \\
\hline & Crepidodera nitidula (Linnaeus, 1758) & E \\
\hline & Cryptocephalus biguttatus (Scopoli, 1763) & E \\
\hline & Cryptocephalus frontalis Marsham, 1802 & 1 \\
\hline & Cryptocephalus laetus Fabricius, 1792 & 1 \\
\hline & Cryptocephalus primarius Harold, 1872 & 1 \\
\hline & Cryptocephalus pygmaeus Fabricius, 1792 & 1 \\
\hline & Cryptocephalus querceti Suffrian, 1848 & $\mathrm{E}$ \\
\hline & Cryptocephalus quinquepunctatus (Scopoli, 1763) & E, Sh \\
\hline & Cryptocephalus saliceti Zebe, 1855 & $\mathrm{~N}, \mathrm{E}$ \\
\hline & Cryptocephalus schaefferi Schrank, 1789 & SE \\
\hline
\end{tabular}




\section{Types of geographical distributio} (Schmitt and Rönn 2011)

\begin{tabular}{|c|c|}
\hline Name of species & $\begin{array}{l}\text { Change in } \\
\text { distribution }\end{array}$ \\
\hline Cryptocephalus sexpunctatus (Linnaeus, 1758) & $\mathrm{E}$ \\
\hline Cryptocephalus signatifrons Suffrian, 1847 & $\mathrm{~N}$ \\
\hline Cryptocephalus variegatus Fabricius, 1781 & 1 \\
\hline Cryptocephalus vittatus Fabricius, 1775 & $\mathrm{E}$ \\
\hline Dibolia foersteri $\mathrm{Bach}, 1859$ & NW, SW, Sh \\
\hline Donacia springeri Müller, 1916 & 1 \\
\hline Epitrix atropae Foudras, 1860 & $\mathrm{E}$ \\
\hline Epitrix intermedia Foudras, 1860 & I \\
\hline Galeruca laticollis (Sahlberg, 1837) & $\mathrm{E}$ \\
\hline Galerucella tenella (Linnaeus, 1760) & $E$ \\
\hline Gonioctena intermedia (Helliesen, 1913) & E, NW \\
\hline Gonioctena linnaeana (Schrank, 1781) & SE, Sh \\
\hline Gonioctena pallida (Linnaeus, 1758) & NE \\
\hline Gonioctena viminalis (Linnaeus, 1758) & $\mathrm{E}$ \\
\hline Hispa atra Linnaeus, 1767 & E, NE \\
\hline Labidostomis humeralis (Schneider, 1792) & S \\
\hline Labidostomis lucida (Germar, 1823) & $\mathrm{N}$ \\
\hline Labidostomis pallidipennis (Gebler, 1839) & I \\
\hline Labidostomis tridentata (Linnaeus, 1758) & E \\
\hline Lilioceris merdigera (Linnaeus, 1758) & 1 \\
\hline Longitarsus absynthii Kutschera, 1862 & 1 \\
\hline Longitarsus echii (Koch, 1803) & $\mathrm{N}, \mathrm{W}$ \\
\hline Longitarsus lateripunctatus (Rosenhauer, 1856) & NW \\
\hline Longitarsus longiseta Weise, 1889 & 1 \\
\hline Longitarsus membranaceus (Foudras, 1860) & 1 \\
\hline Longitarsus minusculus (Foudras, 1860) & I \\
\hline Longitarsus nanus (Foudras, 1860) & SW \\
\hline Longitarsus pellucidus (Foudras, 1860) & $\mathrm{E}$ \\
\hline Longitarsus pulmonariae Weise, 1893 & $\mathrm{~N}, \mathrm{E}$ \\
\hline Longitarsus scutellaris (Rey, 1873) & Sh \\
\hline Luperus flaviceps Apfelbeck, 1912 & $\mathrm{E}$ \\
\hline Mantura mathewsi (Curtis, 1833) & 1 \\
\hline Oomorphus concolor (Sturm, 1807) & $\mathrm{N}, \mathrm{E}$ \\
\hline Orsodacne cerasi (Linnaeus, 1758) & $\mathrm{N}, \mathrm{E}$ \\
\hline Pachnephorus pilosus (Rossi, 1790) & I \\
\hline Pachybrachis hieroglyphicus (Laicharting, 1781) & E \\
\hline Pachybrachis hippophaes Suffrian, 1848 & l \\
\hline Pachybrachis picus Weise, 1882 & Sh \\
\hline Pachybrachis sinuatus Mulsant, 1859 & $\mathrm{E}$ \\
\hline Pachybrachis tessellatus (Olivier, 1791) & E, SE \\
\hline Phaedon laevigatus (Duftschmid, 1825) & NW \\
\hline Phyllotreta christinae Heikertinger, 1941 & E, NW \\
\hline Phyllotreta ochripes (Curtis, 1837) & $\mathrm{N}, \mathrm{E}$ \\
\hline Phyllotreta procera (Redtenbacher, 1849) & S, SE \\
\hline Phyllotreta punctulata (Marsham, 1802) & 1 \\
\hline Prasocuris glabra (Herbst, 1783) & $\mathrm{E}$ \\
\hline Psylliodes chalcomera (Illiger, 1807) & E, W \\
\hline Psylliodes instabilis Foudras, 1860 & 1 \\
\hline Psylliodes isatidis Heikertinger, 1913 & E, S \\
\hline Psylliodes thlaspis Foudras, 1860 & I \\
\hline
\end{tabular}




\section{Types of geographical distributio \\ (Schmitt and Rönn 2011)}

Southern

South-Eastern

\begin{tabular}{|c|c|}
\hline Name of species & $\begin{array}{l}\text { Change in } \\
\text { distribution }\end{array}$ \\
\hline Smaragdina affinis (Illiger, 1794) & SE, Sh \\
\hline Smaragdina flavicollis (Charpentier, 1825) & $\mathrm{NE}$ \\
\hline Timarcha goettingensis (Linnaeus, 1758) & E, Sh \\
\hline Timarcha metallica (Laicharting, 1781) & Sh \\
\hline Timarcha pratensis (Duftschmid, 1825) & 1 \\
\hline Zeugophora frontalis Suffrian, 1840 & 1 \\
\hline Bruchidius marginalis (Fabricius, 1776) & I \\
\hline Bruchus atomarius (Linnaeus, 1761) & $\mathrm{N}, \mathrm{E}$ \\
\hline Cassida ferruginea Goeze, 1777 & 1 \\
\hline Cassida rufovirens Suffrian, 1844 & $\mathrm{~N}$ \\
\hline Cassida sanguinolenta Müller, 1776 & $\mathrm{E}$ \\
\hline Cassida subferruginea (Schrank, 1776) & 1 \\
\hline Cassida subreticulata Suffrian, 1844 & $\mathrm{~N}, \mathrm{E}$ \\
\hline Cassida vibex Linnaeus, 1767 & $\mathrm{E}$ \\
\hline Chrysochus asclepiadeus (Pallas, 1773) & 1 \\
\hline Chrysolina geminata (Paykull, 1799) & I \\
\hline Chrysolina kuesteri (Helliesen, 1912) & $\mathrm{E}$ \\
\hline Chrysolina lichenis (Richter, 1820) & $\mathrm{NE}$ \\
\hline Chrysolina sturmi (Westhoff, 1882) & $\mathrm{E}$ \\
\hline Chrysolina varians (Schaller, 1783) & $\mathrm{E}$ \\
\hline Chrysomela populi Linnaeus, 1758 & $\mathrm{E}$ \\
\hline Chrysomela tremula Fabricius, 1783 & SE \\
\hline Clytra laeviuscula Ratzeburg, 1837 & E, Sh \\
\hline Clytra quadripunctata (Linnaeus, 1758) & $\mathrm{E}$ \\
\hline Coptocephala unifasciata (Scopoli, 1763) & $\mathrm{E}$ \\
\hline Cryptocephalus aureolus Suffrian, 1847 & E, NE \\
\hline Cryptocephalus bilineatus (Linnaeus, 1767) & $\mathrm{E}$ \\
\hline Cryptocephalus chrysopus Gmelin, 1788 & E, W, Sh \\
\hline Cryptocephalus cordiger (Linnaeus, 1758) & SE \\
\hline Cryptocephalus elegantulus Gravenhorst, 1807 & SE \\
\hline Cryptocephalus exiguus Schneider, 1792 & $S$ \\
\hline Cryptocephalus frenatus Laicharting, 1781 & I \\
\hline Cryptocephalus hypochaeridis (Linnaeus, 1758) & E \\
\hline Cryptocephalus marginatus Fabricius, 1781 & 1 \\
\hline Cryptocephalus moraei (Linnaeus, 1758) & $\mathrm{E}$ \\
\hline Cryptocephalus octopunctatus (Scopoli, 1763) & $\mathrm{N}, \mathrm{E}$ \\
\hline Cryptocephalus violaceus Laicharting, 1781 & SE \\
\hline Cryptocephalus vittula Suffrian, 1848 & 1 \\
\hline Dibolia depressiuscula (Letzner, 1847) & I \\
\hline Dibolia femoralis Redtenbacher, 1849 & W \\
\hline Dibolia rugulosa Redtenbacher, 1849 & SE. Sh \\
\hline Galeruca tanaceti (Linnaeus, 1758) & E \\
\hline Gonioctena fornicata (Brüggemann, 1873) & W \\
\hline Gonioctena gobanzi (Reitter, 1902) & $\mathrm{E}$ \\
\hline Labidostomis cyanicornis (Germar, 1817) & Sh \\
\hline Labidostomis longimana (Linnaeus, 1761) & $\mathrm{E}$ \\
\hline Longitarsus apicalis (Beck, 1817) & I \\
\hline Longitarsus ballotae (Marsham, 1802) & $\mathrm{E}$ \\
\hline Longitarsus foudrasi Weise, 1893 & $\mathrm{~N}$ \\
\hline Longitarsus melanocephalus (De Geer, 1775) & $\mathrm{E}$ \\
\hline
\end{tabular}




\begin{tabular}{|c|c|c|}
\hline $\begin{array}{l}\text { Types of geographical distributio } \\
\text { (Schmitt and Rönn 2011) }\end{array}$ & Name of species & $\begin{array}{l}\text { Change in } \\
\text { distribution }\end{array}$ \\
\hline \multirow[t]{11}{*}{ South-Eastern } & Longitarsus nigrofasciatus (Goeze, 1777) & $\mathrm{N}, \mathrm{E}$ \\
\hline & Longitarsus obliteratus (Rosenhauer, 1847) & NE, NW \\
\hline & Longitarsus salviae Gruev, 1975 & I \\
\hline & Mantura obtusata (Gyllenhal, 1813) & / \\
\hline & Minota obesa (Waltl, 1839) & I \\
\hline & Oulema obscura (Stephens, 1831) & $\mathrm{E}, \mathrm{W}$ \\
\hline & Phyllotreta diademata Foudras, 1860 & E, Sh \\
\hline & Phyllotreta nodicornis (Marsham, 1802) & I \\
\hline & Podagrica fuscicornis (Linnaeus, 1767) & E, Sh \\
\hline & Smaragdina aurita (Linnaeus, 1767) & $\mathrm{E}$ \\
\hline & Smaragdina salicina (Scopoli, 1763) & $\mathrm{E}$ \\
\hline South-East & Phyllotreta ganglbaueri Heikertinger, 1909 & I \\
\hline \multirow[t]{12}{*}{ South-Western } & Apteropeda globosa (Illiger, 1794) & $\mathrm{N}$ \\
\hline & Apteropeda splendida Allard, 1860 & I \\
\hline & Bruchus occidentalis Lukjanovitsh \& Ter-Minassian, 1957 & I \\
\hline & Cryptocephalus ocellatus Drapiez, 1819 & $\mathrm{E}$ \\
\hline & Dibolia cryptocephala (Koch, 1803) & E \\
\hline & Donacia bicolora Zschach, 1788 & I \\
\hline & Donacia simplex Fabricius, 1775 & I \\
\hline & Longitarsus aeruginosus (Foudras, 1860) & E, $S$ \\
\hline & Longitarsus ganglbaueri Heikertinger, 1912 & 1 \\
\hline & Longitarsus rubiginosus (Foudras, 1860) & E, W \\
\hline & Mniophila muscorum (Koch, 1803) & SW \\
\hline & Timarcha tenebricosa (Fabricius, 1775) & I \\
\hline \multirow[t]{8}{*}{ Unusual } & Gonioctena decemnotata (Marsham, 1802) & E, W \\
\hline & Gonioctena interposita (Franz \& Palmén, 1950) & E, NW, Sh \\
\hline & Gonioctena olivacea (Forster, 1771) & E, S \\
\hline & Orsodacne humeralis Latreille, 1804 & $\mathrm{E}, \mathrm{W}$ \\
\hline & Oulema duftschmidi (Redtenbacher, 1874) & E, $S$ \\
\hline & Phyllotreta astrachanica Lopatin, 1977 & $\mathrm{NE}$ \\
\hline & Phyllotreta austriaca Heikertinger, 1909 & I \\
\hline & Prasocuris junci (Brahm, 1790) & $\mathrm{E}$ \\
\hline \multirow[t]{4}{*}{ Scattered } & Cryptocephalus quadripustulatus Gyllenhal, 1813 & $\mathrm{E}$ \\
\hline & Oulema erichsonii (Suffrian, 1841) & I \\
\hline & Phyllotreta dilatata Thomson, 1866 & E, NW \\
\hline & Phyllotreta flexuosa (Illiger, 1794) & E, W \\
\hline \multirow[t]{14}{*}{ Wide } & Chrysolina coerulans (Scriba, 1791) & $\mathrm{E}$ \\
\hline & Cryptocephalus coryli (Linnaeus, 1758) & I \\
\hline & Gonioctena quinquepunctata (Fabricius, 1787) & E, NE \\
\hline & Leptinotarsa decemlineata (Say, 1824) & E \\
\hline & Lilioceris lilii (Scopoli, 1763) & I \\
\hline & Oulema melanopus (Linnaeus, 1758) & E, $S$ \\
\hline & Phyllotreta nemorum (Linnaeus, 1758) & $\mathrm{E}, \mathrm{SE}$ \\
\hline & Phyllotreta exclamationis (Thunberg, 1784) & $\mathrm{E}$ \\
\hline & Phyllotreta tetrastigma (Comolli, 1837) & I \\
\hline & Phyllotreta undulata Kutschera, 1860 & SE \\
\hline & Phyllotreta vittula (Redtenbacher, 1849) & E, SE \\
\hline & Zeugophora flavicollis (Marsham, 1802) & 1 \\
\hline & Zeugophora scutellaris Suffrian, 1840 & I \\
\hline & Zeugophora subspinosa (Fabricius, 1781) & $\mathrm{E}$ \\
\hline
\end{tabular}




\section{Appendix 2}

Table 3. List of species and subspecies that were not reported after 1990 (decade 10) or after 2000 (decade 11). Species marked with an asterisk $\left(^{*}\right)$ are pests of stored products, species marked ${ }^{* *}$ were reported informally, but we have no label data in ChryFaun.

\begin{tabular}{|c|c|}
\hline Since & Name of species \\
\hline 1990 & $\begin{array}{l}\text { Aphthona aeneomicans Allard, } 1875 \\
\text { Argopus bicolor Fischer, } 1824 \\
\text { Cassida inquinata Brullé, } 1832 \\
\text { Chrysolina didymata (Scriba, 1791) } \\
\text { Cryptocephalus bimaculatus Fabricius, } 1781 \\
\text { Cryptocephalus bohemius Drapiez, } 1819 \\
\text { Cryptocephalus cyanipes Suffrian, } 1847 \\
\text { Cryptocephalus gridellii Burlini, 1950** } \\
\text { Cryptocephalus loreyi Solier, 1836 } \\
\text { Entomoscelis adonidis (Pallas, 1771)** } \\
\text { Epitrix intermedia Foudras, 1860 } \\
\text { Gonioctena gobanzi (Reitter, 1902) } \\
\text { Longitarsus cizeki Döberl, 2004 } \\
\text { Neocrepidodera basalis (K Daniel, 1900) } \\
\text { Oreina peirolerii (Bassi, 1834) } \\
\text { Orestia heikertingeri Leonardi, 1974 } \\
\text { Prasocuris (Hydrotassa) flavocincta (Brullé, 1832) } \\
\text { Psylliodes gibbosa Allard, 1860 } \\
\text { Psylliodes kiesenwetteri Kutschera, 1864 } \\
\text { Psylliodes luteola (Müller, 1776) } \\
\text { Stylosomus ilicicola Suffrian, 1848 } \\
\text { Timarcha nicaeensis(Villa \& Villa 1835) }\end{array}$ \\
\hline
\end{tabular}




\begin{tabular}{|c|c|}
\hline Since & Name of species \\
\hline 2000 & $\begin{array}{l}\text { Cryptocephalus planifrons Weise, 1882** } \\
\text { Cryptocephalus quatuordecimmaculatus Schneider, 1792** } \\
\text { Cryptocephalus transiens Franz, 1949** } \\
\text { Cryptocephalus virens Suffrian, 1847** } \\
\text { Derocrepis sodalis (Kutschera, 1860) } \\
\text { Entomoscelis sacra (Linnaeus, 1758)** } \\
\text { Galeruca jucunda (Faldermann, 1837) } \\
\text { Gonioctena kaufmanni (Miller, 1880)** } \\
\text { Gonioctena variabilis (Olivier, 1790) - probably incorrect identification } \\
\text { Labidostomis pallidipennis (Gebler, 1839) } \\
\text { Lachnaia italica (Weise, 1882) } \\
\text { Longitarsus weisei Guillebeau, 1895 } \\
\text { Luperus nigripes Kiessenwetter, 1861** } \\
\text { Minota alpina Biondi, 1986 } \\
\text { Minota impuncticollis (Allard, 1860) } \\
\text { Neocrepidodera adelinae (Binaghi, 1947) } \\
\text { Neocrepidodera cyanipennis (Kutschera, 1860) } \\
\text { Neocrepidodera obirensis (Ganglbauer, 1897) } \\
\text { Neocrepidodera simplicipes (Kutschera, 1860) } \\
\text { Oreina liturata (Scopoli, 1763) } \\
\text { Orestia electra Gredler, } 1868 \\
\text { Phyllobrotica adusta (Creutzer, 1799) } \\
\text { Phyllotreta consobrina (Curtis, 1837) } \\
\text { Phyllotreta ziegleri Lohse, 1980 } \\
\text { Psylliodes danieli Weise, } 1900 \\
\text { Psylliodes rambouseki forojulensis Heikertinger, 1926 } \\
\text { Psylliodes subaenea styriaca Heikertinger, 1921 } \\
\text { Smaragdina diversipes Letzner, 1839** } \\
\text { Zabrotes subfasciatus (Boheman, 1833)* }\end{array}$ \\
\hline
\end{tabular}

